\title{
China's Beech Forests in the Pre-Quaternary
}

\author{
Liu Yu-Sheng ${ }^{1}$, Wang Wei-Ming ${ }^{2}$ \& Arata Momohara ${ }^{3}$ \\ With 1 plate and 7 figures
}

\begin{abstract}
Fagus in China is never dominant in Late Cretaceous and Tertiary floras although it might reach its highest diversity in the Miocene. The genus Fagus was more widely distributed during the Palaeogene than in the Neogene. Furthermore, the ecological requirements of Fagus in the Palaeogene seem much broader than those in the Neogene onwards. This is because the Palaeogene floras containing Fagus lived in various conditions from an arid and hot climate to a humid and warm habitat. Additionally, Fagus then coexisted with many kinds of hygrophilous, thermophilous and xerophilous plants. However, the wide distribution, broad ecological adaptation and species composition changed greatly in the Neogene. The Neogene Faguscontaining floras are slightly more similar to the modern beech forests than the Palaeogene ones, although a big difference remains. Chinese fossil data document the post-Tertiary development of the modern beech forests.
\end{abstract}

Key words: China, Fagus, forest change, mega-/microfossils, pre-Quaternary

\section{Introduction}

Fagus (beech) is one of the most important trees in the temperate and subtropical forests of the Northern Hemisphere (Peters 1997). There are eleven species in total, seven occur in China. The Chinese species are of significance because their occurrence is restricted to the montane region of south China where they associate with numerous evergreen trees (Chang \& Huang 1988, Zhou \& Li 1994; Cao et al. 1995; Peters 1997). Moreover, it is believed that these species are so sensitive to heat and water conditions that they do not occur in lowland area of China (Hong \& An 1993; Cao et al. 1995).

An attempt has been made to explain the pre-Quaternary development of Fagus forests in China (Zhou \& Li 1994; Peters 1997). However, these studies are mostly based on incomplete literature data including many errors. In the present paper, all the fossil data of Fagus from China are applied after a careful review (Liu et al. 1996; Leng 1997; Wang Wei-Ming unpublished data) to analyse the development of Fagus forests in the pre-Quaternary of China. The main objective is to understand the evolutionary his- tory of beeches from floristic and ecological points of view.

\section{Methods}

There is one living beech endemic to Taiwan (see Table 1). As little information on the fossil records of Fagus is available, our discussion will concentrate on continental China.

Identification of fossil leaves and pollen grains belonging to the genus Fagus is not always easy. Furthermore, it is probably even more difficult to establish the interspecific relationships of fossil and living taxa because of the high variation in leaf morphology within the genus (Shen 1992; Liu \& Momohara submitted). In order to find useful criteria to classify fossil leaves into the natural groups of Fagus, many palaeobotanists have tried to find characters for distinguishing infrageneric taxa, such as the number of secondary veins, leaf index and foliar cuticles (Tanai 1974; Zetter 1984; Kvacek \& Walther 1991). Foliar macrocharacters may not be as valuable as has been claimed, although they are easily observed (Liu \& Momohara submitted). Leaf cuti-

\footnotetext{
1 Museum of Natural History, Institute of Palaeontology, Invalidenstrasse 43, D-10115 Berlin, Germany, and Department of Palaeobotany, Nanjing Institute of Geology \& Palaeontology, Academia Sinica, Nanjing 210008, China

2 Department of Palynology, Nanjing Institute of Geology \& Palaeontology, Academia Sinica, Nanjing 210008, China

3 Department of Environmental Studies, Chiba University, 648 Matsudo, Matsudo City, Chiba, 271 Japan. Received March, accepted Juni 1998
} 
cles are ideal to be applied in the classification of fossil beeches but they are by no means always preserved. Fossil leaves attributed to Fagus in China are largely preserved as impressions (Liu et al. 1996). A recent discovery of some beech leaves in the Miocene of northeast China did yield carbonized material but only the upper cuticle has been obtained (Leng 1997). Therefore, this does not provide much help to figure out the relationships between the fossil and living beeches in China. Therefore, fossil organ-species of beeches with little evolutionary significance are used in the paper (Liu et al. 1996; Leng 1997). On the other hand, unlike the pollen of Nothofagus, the pollen morphology in Fagus does not seem to provide features useful for safe identification of all species (Praglowski 1982).

Most Fagus fossils are recovered from terrestrial sediments. The dating is certainly sometimes controversial. In the present paper, we follow Zhang (1993, 1995) for the Late Cretaceous and Palaeogene palynofloras respectively, Liu (1988) and Wang (1992) for the Neogene palynofloras and Liu et al (1996) for the Cenozoic megafloras.

\section{Recent beech forests in China}

Seven species (including 1 variety) endemic to China have been so far documented (Chang \& Huang 1988; Anonymous 1992). They are unique not only systematically but geographically and ecologically as well (Zhou \& Li 1994; Cao et al.
1995; Liu \& Momohara submitted).

1. Distribution: The Chinese Fagus species are restricted to the subtropical montane region in south China, appearing mainly between $700 \mathrm{~m}$ and $2500 \mathrm{~m}$ above sea level. They only occur as components in vertical vegetation zones between south of ca. $34^{\circ} \mathrm{N}$ and north of ca. $22^{\circ} \mathrm{N}$ (Fig. 1 ; Table 1). In a vertical zonation, they are found close to the upper limit of evergreen broadleaved forests or sometimes in a the transitional vegetation type extending into deciduous broadleaved forests. It is interesting to note that they do not occur in any horizontal vegetation zone in the same region. This is very different from their distribution pattern in Europe, Japan and North America where beeches mainly occur in the temperate deciduous forest region of both lowland and montane areas.

The distribution of each Chinese beech species is shown in Table 1.

2. Ecological requirements: Cao et al. (1995) presented a full and detailed survey of the ecological conditions of Fagus in China, and concluded that all the Chinese beeches require similar water and heat conditions. For Chinese beeches habitats with an annual precipitation of $740-3500 \mathrm{~mm}$ and a mean annual temperature ranging from 5 to $17^{\circ} \mathrm{C}$ are optimal (Table 2). Table 2 shows the basic differences between the Chinese beeches and the others in a simple way. The habitats in China's beech forests are more humid than those in lowland Europe and North America (Cao et al. 1995).

Table 1

Geographical ranges of Fagus in China and the forest types in which they live (based on Xu et al. 1985; Chang \& Huang 1988; Anonymous 1992; Liao 1994; Cao et al. 1995).

\begin{tabular}{|c|c|c|c|c|c|}
\hline \multirow[t]{2}{*}{ Taxon } & \multirow{2}{*}{$\begin{array}{l}\text { Latitude } \\
\left({ }^{\circ} \mathrm{N}\right)\end{array}$} & \multirow{2}{*}{$\begin{array}{l}\text { Longitude } \\
\left({ }^{\circ} \mathrm{E}\right)\end{array}$} & \multicolumn{2}{|l|}{$\begin{array}{l}\text { Altitude } \\
(\mathrm{m})\end{array}$} & \multirow[t]{2}{*}{ Forest } \\
\hline & & & E. of $107^{\circ} \mathrm{E}$ & W. of $107^{\circ} \mathrm{E}$ & \\
\hline Fagus chienii Cheng & 33 & 104 & & 1300 & mixed forest \\
\hline F. engleriana Seem. & $27.5-34.3$ & $102.2-119.4$ & $1000-2000$ & $1200-2500$ & mixed forest or rare pure stands \\
\hline F. hayatae Palib. ex Hayata & 24.7 & 121.4 & $1300-1500$ & & $\begin{array}{l}\text { associated with Trochodendron, } \\
\text { Illicium, Mahonia, Adinanthera } \\
\text { and Daphniphyllum etc. }\end{array}$ \\
\hline $\begin{array}{l}\text { F. hayatae var. zhejiangensis } \\
\text { Liu et } \mathrm{Wu}\end{array}$ & 28.2 & 120.8 & 850 & & broadleaved foresi \\
\hline F. longipetiolata Seem. & $22.3-32.7$ & $101.2-121.5$ & $300-1500$ & $800-2500$ & $\begin{array}{l}\text { mixed evergreen and deciduous } \\
\text { broadleaved forest }\end{array}$ \\
\hline F. lucida Rehd. et Wils. & $24.3-32.0$ & $103.2-120.8$ & $800-2000$ & $1800-2200$ & $\begin{array}{l}\text { pure stands or mixed with other } \\
\text { moutainous deciduous broadlea- } \\
\text { ved trees }\end{array}$ \\
\hline F. pashanica Yang & $\begin{array}{l}30.3 \\
32.7-33.5\end{array}$ & $\begin{array}{l}119.4 \\
105-107\end{array}$ & $900-1000$ & $1200-1900$ & $\begin{array}{l}\text { mixed forest } \\
\text { mixed needle/deciduous broadlea- } \\
\text { ved forest; rare pure stands. }\end{array}$ \\
\hline
\end{tabular}




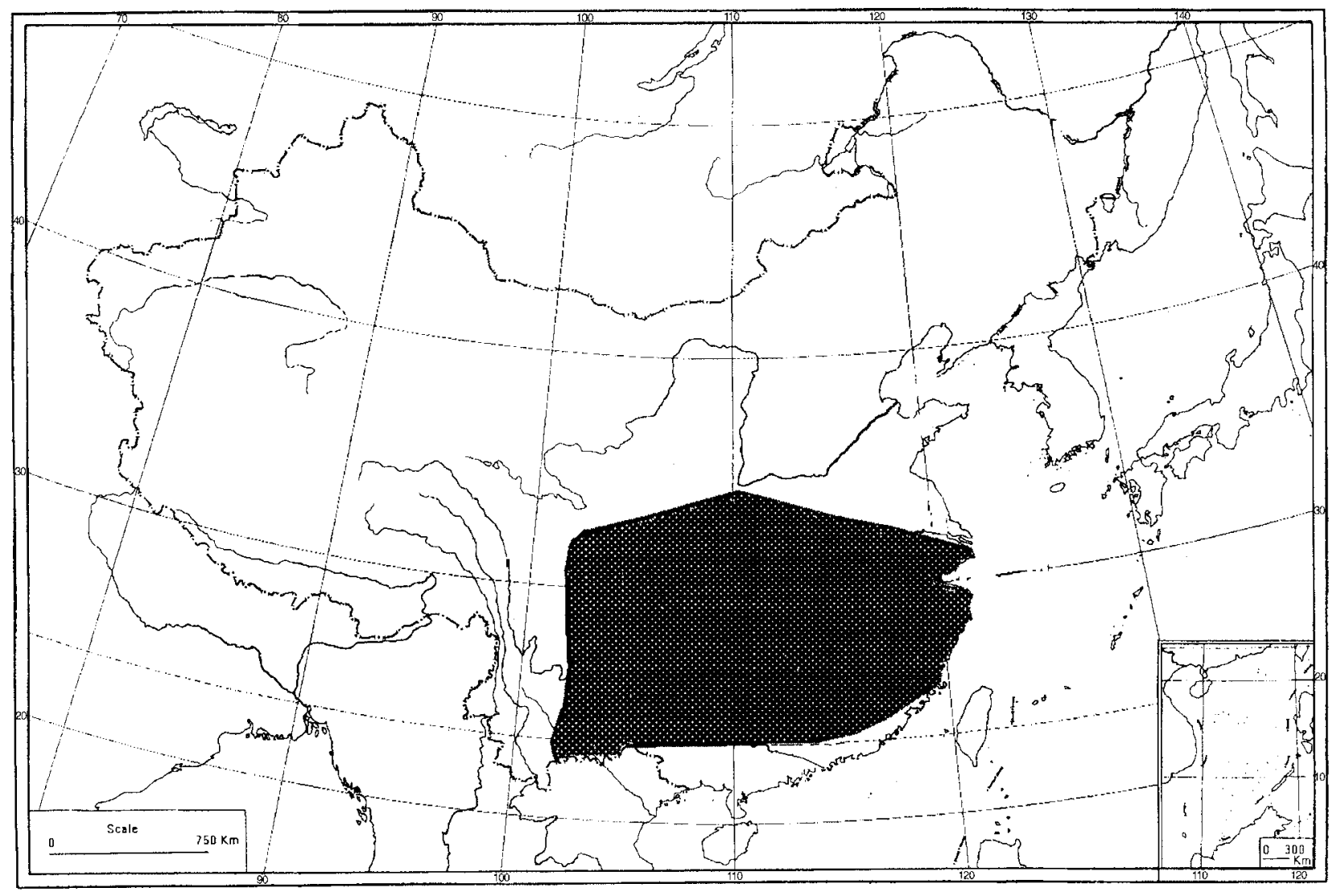

Fig. 1. Distribution of living Fagus in China (after Tsien et al. 1975; Chang \& Huang 1988; Hong \& An 1993; Cao et al. 1995; Peters 1997)

The principal factor controlling the distribution of Chinese beeches is the precipitation during the growing season, while the temperature condition is another important factor (Hong \& An 1990). It is therefore reasonably explained that Chinese beeches are limited by a moisture deficit in the north, and by high temperatures plus relatively low moisture levels in the south (Cao et al. 1995). Of course, soil conditions can also be important (Zhou \& Li 1994).

Table 2

Ecological comparison of Fagus species in China, Japan, Europe and North America (after Cao et al. 1995).

\begin{tabular}{lcr}
\hline Taxon & $\begin{array}{l}\text { Mean annual } \\
\text { temperature } \\
\left({ }^{\circ} \mathrm{C}\right)\end{array}$ & $\begin{array}{l}\text { Precipitation } \\
(\mathrm{mm})\end{array}$ \\
\hline Fagus chienii Cheng & $12.0-13.0$ & $980-1150$ \\
F. engleriana Seem. & $4.8-13.9$ & $740-2400$ \\
F. hayatae Palib. ex Hayata & $12.0-17.0$ & $2800-3500$ \\
F. hayatae var zhejiangensis & $12.5-16.5$ & $2800-3500$ \\
$\quad$ Liu et Wu & $6.0-16.7$ & $850-2770$ \\
F. longipetiolata Seem. & $7.4-14.2$ & $1200-2700$ \\
F. lucida Rehd. et Wils. & $6.6-9.6$ & $1300-1550$ \\
F. pashanica Yang & $3.0-13.0$ & $1200-3400$ \\
F. crenata Blume & $2.0-14.0$ & $500-2000$ \\
F. sylvatica Linn. & $3.0-21.0$ & $760-2100$ \\
F. grandifolia Ehrh. & &
\end{tabular}

3. Forest types: Beech species are mainly canopy elements in the subtropical montane region of China. Although these forests share some genera with other beech forests in the North Hemisphere, they are not homogeneous in species composition because of different floral development and climatic change in the geological past (Zhou \& Li 1994; Peters 1997; for full list of species composition, refers to Peters 1997).

Based on the composition of tree species cooccurring with beeches in the canopy, Peters (1997) recognized three major beech forest groups worldwide in which can be further subdivided into about fourteen beech forest types. The three groups are characterised as follows:

I. beech species appearing with evergreen coniferous species - which can be found in North America, Turkey, Europe and Japan;

II. beech species co-occurring with deciduous broadleaved species - which can be seen in North America, Europe, Japan and China;

III. beech species living with evergreen broadleaved trees - which can be seen in U.S.A., Mexico, Japan and China. 
There are two types of beech forests in China (Zhou \& Li 1994; Peters 1997). In southern China (about $25-30^{\circ} \mathrm{N}$ ), beech species like Fagus lucida or $F$. longipetiolata occur with evergreen and deciduous trees. Evergreen genera are like Manglietia and Michelia (Magnoliaceae), Illicium (Illiciaceae), many genera of the Lauraceae and the Theaceae, Castanopsis, Cyclobalanopsis, and Lithocarpus (Fagaceae), Symplocos (Symplocaceae), Elaeocarpus (Elaeocarpaceae), Idesia (Flacourtiaceae), Clethra (Clethraceae), Nyssa (Nyssaceae), Mallotus (Euphorbiaceae), Daphniphyllum (Daphniphyllaceae), Rhus (Anacardiaceae), while deciduous genera include Cercidiphyllum (Cercidiphyllaceae), Liquidambar (Hamamelidaceae), Betula (Betulaceae), Rhododendron (Ericaceae), Prunus, Photinia, and Eriobotrya (Rosaceae), and Acer (Aceraceae). On the other hand, in the regions of $28-32^{\circ} \mathrm{N}$ of central-southern China, beech forests are dominated by Fagus lucida (south), F. hayatae (north), $F$. engleriana and some other deciduous genera such as the conifers Pinus and Abies, Carpinus and Betula (Betulaceae), Quercus and Castanea (Fagaceae), Tilia (Tiliaceae), Prunus, Sorbus, and Photinia (Rosaceae), Cornus (Cornaceae), Hovenia (Rhamnaceae), Aesculus (Hippocastanaceae), Acer (Aceraceae), Juglans and Platycarya (Juglandaceae). Evergreen genera such as Magnolia (Magnoliaceae), Cyclobalanopsis (Fagaceae), Nyssa (Nyssaceae) also occur although they are only a few (Tsien et al. 1975; Zhou \& Li 1994; Peters 1997).

It is evident that numerous genera which are comparatively commonly encountered in the Tertiary floras of China seem not to be present in modern Chinese beech forests (see Liu et al. 1996). According to Peters (1997), these genera include Picea and Tsuga (Pinaceae), Taxus (Taxaceae), Ostrya (Betulaceae), Morus (Moraceae), Amelanchier (Rosaceae), Cercis and Gymnocladus (Leguminosae), Phellodendron (Rutaceae), Carya (Juglandaceae) and Aralia (Araliaceae), and several genera of the Ulmaceae, e.g., Ulmus, Celtis and Zelkova.

In summary, there are mainly two basic types of beech forests in the subtropic montane region of south China. They occupy the region ranging from south of $32^{\circ} \mathrm{N}$ to north of $20^{\circ} \mathrm{N}$ and at altitudes from 700 to $2500 \mathrm{~m}$. One type of the beech forest is characterized by the co-occurrence with dominant deciduous trees although some evergreen broadleaved species are also present, whereas the another is the main type of Chinese beech forests in which more evergreen trees present with beeches. Chinese beeches are quite susceptible to both humidity, temperature and soil conditions.

\section{Fossil beech forests in China}

Fossil records of Fagus, especially the pollen grains are quite common throughout China from the Late Cretaceous onwards (Tables 3 and 4). However, it is necessary to mention that the microfossils of Fagus in China never dominated in any pre-Quaternary assemblage although they might reach their acme in the Miocene or maybe late in the Pliocene (Pliocene fossil beeches are rarely recovered in China). This is also partly supported by a handful of macrofossils assignable to this genus from China. Hence, the lower abundance of Fagus in Chinese pollen diagrams may not be biased by sampling. Several explanations can be given. First, it could be that the Chinese Fagus had only been in a subordinate position in the ancient forests and never formed pure stands like today because of failure in competition with other trees (see Cao et al. 1995). Evergreen and/or deciduous trees were probably well-developed throughout the Tertiary in China as in many areas where fossil Fagus were found. Consequently, the beech fossil pollen constitute only a relatively low percentage in an assemblage. Secondly, the ancient Fagus in China would be prosperous, but restricted to a fairly high montane region which limits the possibility to be fossilized. In addition, this supposal could not explain why a lot of fossil beeches are frequently recovered in the adjacent areas like Japan (see Tanai 1974). Thirdly, in several cases beech fossils have not been recognized as such and were misidentified. As far as the pollen morphology of beeches is concerned, it is generally clear enough to enable a correct identification when dealing with fossil pollen, although modern palynologists sometimes do not agree on some morphological characters of Fagus, e.g. the colpus morphology (see Praglowski 1982; Wang \& Chang 1991). Furthermore, beech leaf fossils are sometimes easily wrongly identified (Tanai 1974; Liu et al. 1996). According to the data available, we tend to support the first hypothesis.

1. Fagus in the Cretaceous: There are two published Late Cretaceous records of Fagus pollen grains of northeast (Anonymous 1976; Yu et al. 1983) and southeast China (Song et al. 1986), respectively (Fig. 2). In both cases Fagus occurs in an extremely low percentage (Table 3 ). The 


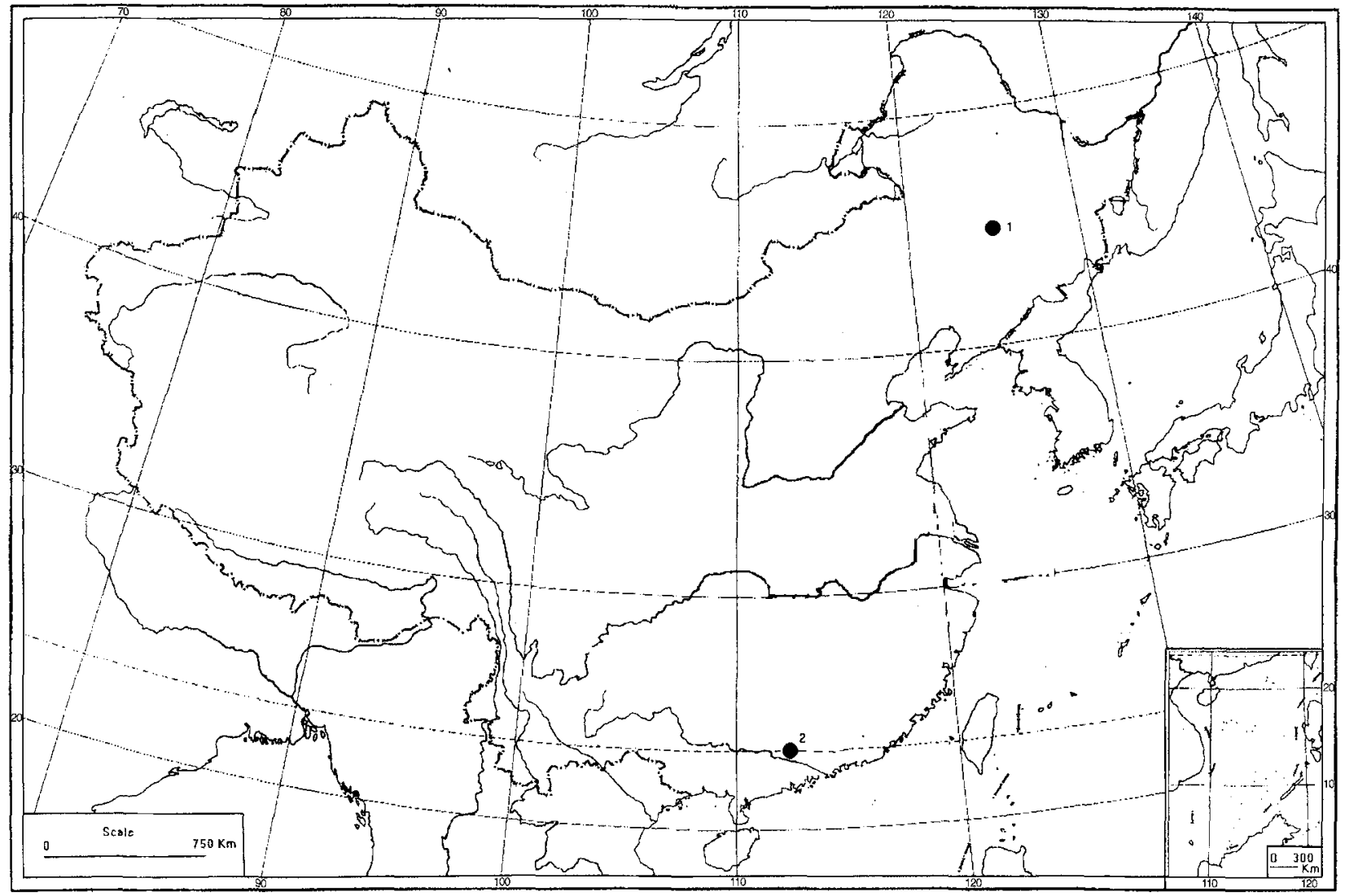

Fig. 2. Occurrences of Fagus in the Cretaceous (the Arabic numerals correspond to the number of localities in Table 3)

identification of these fossil pollen grains might however be questionable as Song et al. (1986) stated that the fossil species (named as Faguspollenites tenuis Song, $\mathrm{Li}$ et Zhong, 1986) from southeast China shows only a morphological resemblance with Faguspollenites and its relationship with Fagus is still unclear. As the two samples are not available for us, we can not discuss them further. Nevertheless, it may be possible that the ancestors of Fagus appeared in the Late Cretaceous because in the Palaeocene Fagus was already widely distributed (Fig. 3).

2. Fagus in the Palaeogene: The distribution of Fagus in the Palaeogene was the widest through the whole geological history of beeches in China (Figs 2-5) in spite of the normally fairly low abundances. Most of the fossils are pollen (Table 3 ), whereas only a few are leaves (Table 4).

There are no megafossils of Fagus found in the Palaeocene, but the pollen grains of the genus seem to occur throughout the country except for southwest China (Fig. 3), however in fairly low percentages. The highest percentage recorded $(5 \%)$ is from the southern part of the country - Sanshui Basin of Guangdong Province
(Song et al. 1986). The Palaeocene beeches seem to live in two completely different climates (Guo $1985,1990)$. One is a moist and warm temperate climate in the northeast (Liu 1983), while the other is a torrid and arid climate in the central and south (Li 1980; Wang \& Zhao 1980; Song et al. 1981, 1985, 1986; Zhao 1982; Wang et al. 1987; Wang 1990). Neither of the climates appear not to fit in with the ecological requirements of modern beeches. Floristically, associated taxa in the fossil floras are quite different with those in the living beech forests. For example, one palynoflora from Jiayin County, northeast China has the following dominant members: Betulaceae, Ulmaceae, Juglandaceae and Myricaeae (Liu 1983). However, Ulmaceae and Myricaeae no longer occur in the Chinese living beech forests (Peters 1997).

In the Eocene, fossil leaves of Fagus are found in southwest China (Table 4, Fig. 4; Zhang 1983; Liu et al. 1996). However, because of their poor preservation, these fossils can not be definitely assigned to Fagus. On the other hand, the pollen records reveal more complete distribution patterns than the leaves. And again, the occurrences of the Eocene beech pollen are still low. Additionally, it is strange that beeches seem to 
Table 3

Occurrences of fossil Fagus pollen in the pre-Quaternary of China (mostly based on Wang Wei-Ming unpublished data).

\begin{tabular}{|c|c|c|c|c|}
\hline Locality & Stratum & Age & Content $(\%)$ & Reference \\
\hline 1. Songliao Basin, N.E. China & Mingshui Form. & Maastrichtian & $0-1.2$ & $\begin{array}{l}\text { Anonymous } 1976 \\
\text { Yu et al. } 1983\end{array}$ \\
\hline 2. Sanshui Basin, S.E. China & Dalangshan Form. & $\begin{array}{l}\text { Late Cenomanian- } \\
\text { Maastrichtian }\end{array}$ & sparse & Song et al. 1986 \\
\hline 3. Jiayin, N.E. China & Wuyun Form. & Late Palaeocene & sparse & Liu 1983 \\
\hline $\begin{array}{l}\text { 4. Coastal region of Bohai Sea } \\
\text { and Bohai Sea, N.E. China }\end{array}$ & $\begin{array}{l}\text { Shahejie and } \\
\text { Dongying Form. }\end{array}$ & Late Eocene-Oligocene & $0-1.2$ & $\begin{array}{l}\text { Anonymous } 1978 ; \\
\text { Guan et al. } 1989 \\
\text { Yananoi e1 al } 1993\end{array}$ \\
\hline 5. N. Jiangsu, E. China & $\begin{array}{l}\text { Uppermost of } \\
\text { Taizhou Form. } \\
\text { Funing Form. } \\
\text { Dainan Form. }\end{array}$ & $\begin{array}{l}\text { Danian } \\
\text { Late Palaeocene } \\
\text { Early Eocene }\end{array}$ & $\begin{array}{l}0-1.0 \\
0-1.0 \\
\text { sparse }\end{array}$ & $\begin{array}{l}\text { Song et al. 1981; } \\
\text { Zhang \& Qian } 1992\end{array}$ \\
\hline 6. Hefei Basin, E. China & Dingyuan Form. & Palaeocene-Eocene & $0-3.1$ & Wang et al. 1987 \\
\hline 7. Shelf Basin of East China Sea & $\begin{array}{l}\text { Lingfeng Form. } \\
\text { Huagang Form. }\end{array}$ & $\begin{array}{l}\text { Late Palaeocene } \\
\text { Oligocene }\end{array}$ & $\begin{array}{l}\text { sparse } \\
0-1.2\end{array}$ & $\begin{array}{l}\text { Song et al. } 1985 \\
\text { Anonymous } 1989\end{array}$ \\
\hline 8. Cixi, E. China & Changhe Form. & Palaeocene-Eocene & sparse & Li 1480 \\
\hline 9. Nanling, E. China & Shuangta Group & Oligocene & sparse & Wang et al. 1987 \\
\hline 10. Jianghan Area, C. China & $\begin{array}{l}\text { Xingouju Form. } \\
\text { Qianjiang Form. }\end{array}$ & $\begin{array}{l}\text { Palaeocene-Eocene } \\
\text { Middle-Late } \\
\text { Oligocene }\end{array}$ & $\begin{array}{l}\text { sparse } \\
1-2.0\end{array}$ & $\begin{array}{l}\text { Wang \& Zhao 1980; } \\
\text { Li et al. } 1978\end{array}$ \\
\hline 11. Songci, C. China & $\begin{array}{l}\text { Yangxi and } \\
\text { Pailoukou Form. }\end{array}$ & Eocene & sparse & Lei et al. 1987 \\
\hline 12. Sanshui Basin, S.E. China & $\begin{array}{l}\text { Buxin Group } \\
\text { Xibu Form. }\end{array}$ & $\begin{array}{l}\text { Palaeocene } \\
\text { Early Eocene }\end{array}$ & $\begin{array}{l}0-5.0 \\
\text { sparse }\end{array}$ & $\begin{array}{l}\text { Song et al. 1986; } \\
\text { Li \& Qing } 1994\end{array}$ \\
\hline $\begin{array}{l}\text { 13. Xining-Minghe Basin, } \\
\text { N.W. China }\end{array}$ & $\begin{array}{l}\text { Qijiachuan Form. } \\
\text { Honggou Form. }\end{array}$ & $\begin{array}{l}\text { Palaeocene } \\
\text { Early Eocene } \\
\text { Eocene }\end{array}$ & $\begin{array}{l}0-1.0 \\
0-2.0\end{array}$ & Wang et al. 1990 \\
\hline 14. Changdu, S.W. China & Gonjo Form. & Late Eocene & sparse & Song \& L.j 1982 \\
\hline 15. Kuche Basin, N.W. China & $\begin{array}{l}\text { Talake Form. } \\
\text { Xiaokuzibai Form. } \\
\text { Suweiyi Form. }\end{array}$ & $\begin{array}{l}\text { Early Palacocene } \\
\text { Early Eocene } \\
\text { Middle-Late Eocene } \\
\text { to Early Oligocene }\end{array}$ & $\begin{array}{l}1.0-2.0 \\
2.0 \\
1.0\end{array}$ & Zhao et al. 1982 \\
\hline 16. Tarim Basin, & Wulageng Form. & Middle Eocene & sparse & Wang et al. 1990 \\
\hline $\begin{array}{l}\text { 17. Coastal region of Bohai Sea } \\
\text { and Bohai Sea, N.E. China }\end{array}$ & $\begin{array}{l}\text { Guantao Form. } \\
\text { Minghuazhen Form. }\end{array}$ & $\begin{array}{l}\text { early Middle } \\
\text { Miocene } \\
\text { Miocene-Pliocene }\end{array}$ & $\begin{array}{l}0-6.7 \\
0-7.6\end{array}$ & $\begin{array}{l}\text { Anonymous } 1978 \\
\text { Guan et al. } 1989 ; \\
\text { Yamanoi et al } 1993\end{array}$ \\
\hline 18. Shanwang Basin, E. China & Shanwang Form. & early Middle Miocene & $2.8-8.1$ & $\begin{array}{l}\text { Liu 1986; } \\
\text { Liu \& Leopold } 1992\end{array}$ \\
\hline 19. N. Jiangsu, E. China & $\begin{array}{l}\text { Lower Yancheng } \\
\text { Group }\end{array}$ & early Middle Miocene & $0-1.0$ & SONG et al. 1981 \\
\hline 20. Tianchang, E. China & Strata unnamed & Early Miocene & $1.3-3.0$ & Zheng \& Zhang 1986 \\
\hline 21. Fuyang Area, E. China & Strata unnamed & Miocene & $0.8-1.2$ & Wang et al. 1987 \\
\hline 22. Shelf Basin of East China Sea & $\begin{array}{l}\text { Hailonging and } \\
\text { Yuquan Form. } \\
\text { Santan Form. }\end{array}$ & $\begin{array}{l}\text { Miocene } \\
\text { Pliocene }\end{array}$ & $\begin{array}{l}\text { sparse } \\
0-1.8\end{array}$ & $\begin{array}{l}\text { Song et al. } 1985 \\
\text { Anonymous } 1989\end{array}$ \\
\hline 23. E. Zhejiang, E. China & Strata unnamed & Miocene & $0-1,6$ & $\begin{array}{l}\text { Wang et al. 1985; } \\
\text { Zheng } 1982\end{array}$ \\
\hline 24. Yalong, S.W. China & Strata unnamed & $\begin{array}{l}\text { late Early Miocene- } \\
\text { early Middle Miocene }\end{array}$ & $0.9-1.0$ & Wang 1989 \\
\hline 25. Zhaotong, S.W. China & Strata unnamed & Early Pliocene & $0-3.2$ & Song 1988 \\
\hline
\end{tabular}




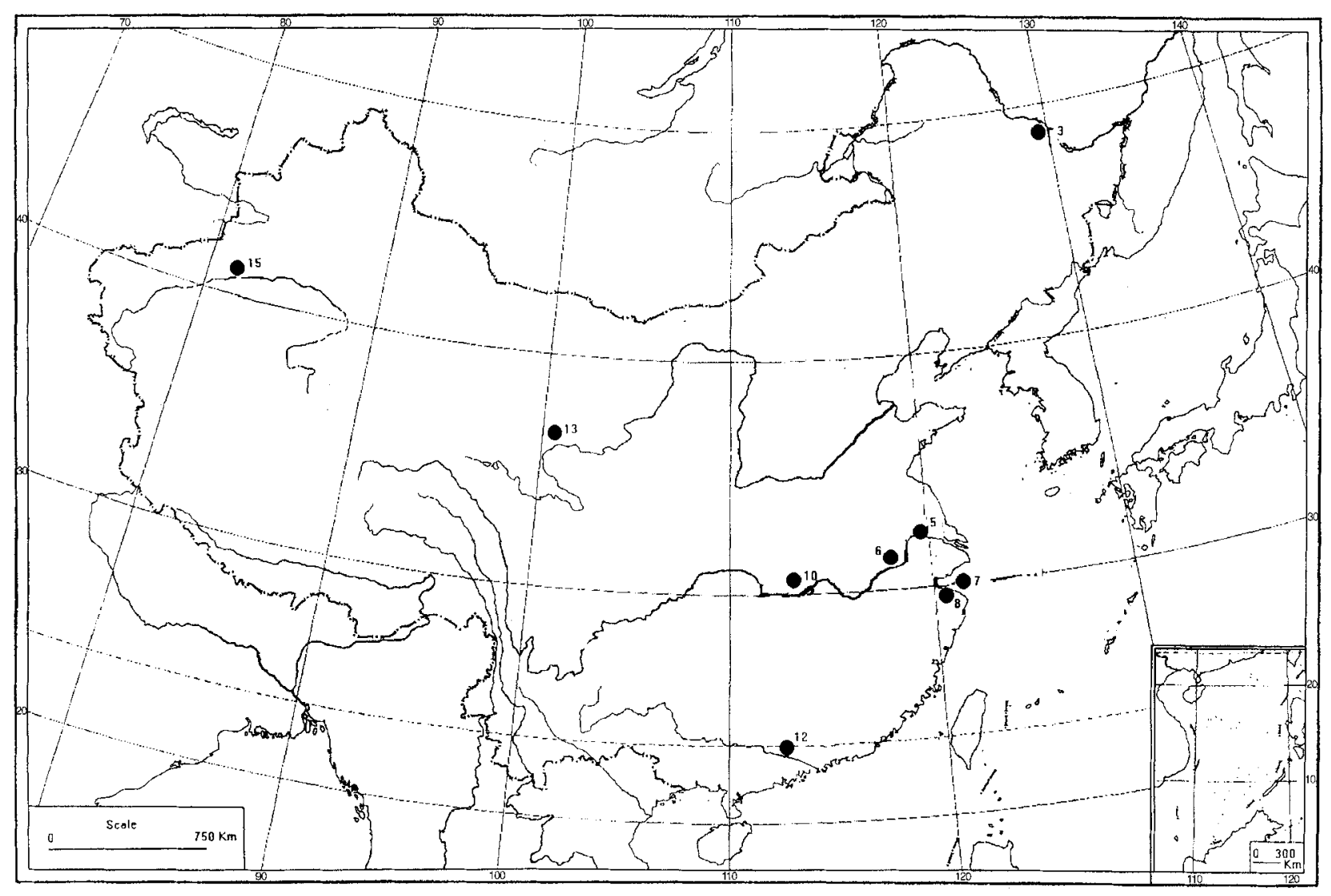

Fig. 3. Occurrences of Fagus in the Palaeocene (the Arabic numerals correspond to the number of localities in Table 3)

retreat from northeast China, where climate was still humid and warm then (northern subtropical or warm temperate conditions) (Guo 1985, 1990). The difference in distribution of Fagus with that in the Palaeocene is that beeches seem to invade further south to the southwest (Song
\& Li 1982; Zhang 1983) and west to the northwest (Wang et al. 1990). All the Eocene beeches occupy the areas with an arid and subtropical climate (Guo 1985, 1990; Li \& Zheng 1995). It is not easy to understand why Fagus as a typical hygrophilous genus could survive there because

Table 4

Summary of megafossil species of Fagus in China (mostly based on Liu et al. 1996; Leng 1997).

\begin{tabular}{|c|c|c|c|c|}
\hline Locality & Taxon & Age & Occurrence & Reference \\
\hline 26. Panxian, S.W. China & Fagus sp. 1 & $\begin{array}{l}\text { Late Eocene to } \\
\text { Early Oligocene }\end{array}$ & 2 fragments & Zhang 1983 \\
\hline 27. Yanji, N.E. China & $\begin{array}{l}\text { F. galbanifolia } \\
\text { F. sp. } 2\end{array}$ & $\begin{array}{l}\text { Late Oligocene } \\
\text { Late Oligocene }\end{array}$ & $\begin{array}{l}8 \text { leaves } \\
3 \text { leaves }\end{array}$ & $\begin{array}{l}\text { Guo } 1992 \\
\text { Guo } 1992\end{array}$ \\
\hline 28. Weichang, N.E. China & F. engleriana & Miocene & several leaves & Depape 1932 \\
\hline 29. Dunha, N.E. China & F. stuxbergi & Middle Miocene & 13 leaves & Li \& Yang 1984 \\
\hline \multirow[t]{5}{*}{ 30. Huanan, N.E. China } & F. altaensis & $\begin{array}{l}\text { Middle-Late } \\
\text { Miocene }\end{array}$ & 19 leaves & Leng 1997 \\
\hline & F. antipofii & $\begin{array}{l}\text { Middle-Late } \\
\text { Miocene }\end{array}$ & 16 leaves & Leng 1997 \\
\hline & F. florinii & $\begin{array}{l}\text { Middle-Late } \\
\text { Miocene }\end{array}$ & 1 fragment & Leng 1997 \\
\hline & F. silesiaca & $\begin{array}{l}\text { Middle-Late } \\
\text { Miocene }\end{array}$ & 3 fragments & Leng 1997 \\
\hline & $F$ sp. & $\begin{array}{l}\text { Middle-Late } \\
\text { Miocene }\end{array}$ & 1 fragment & Leng 1997 \\
\hline 31. Nanfeng, S.E. China & F. praelucida & Pliocene & 1 leaf & Li \& Guo 1982 \\
\hline 32. Panxian, S.W. China & F. sp. 3 & Early Pleistocene & some cupules & Zhang 1978 \\
\hline
\end{tabular}



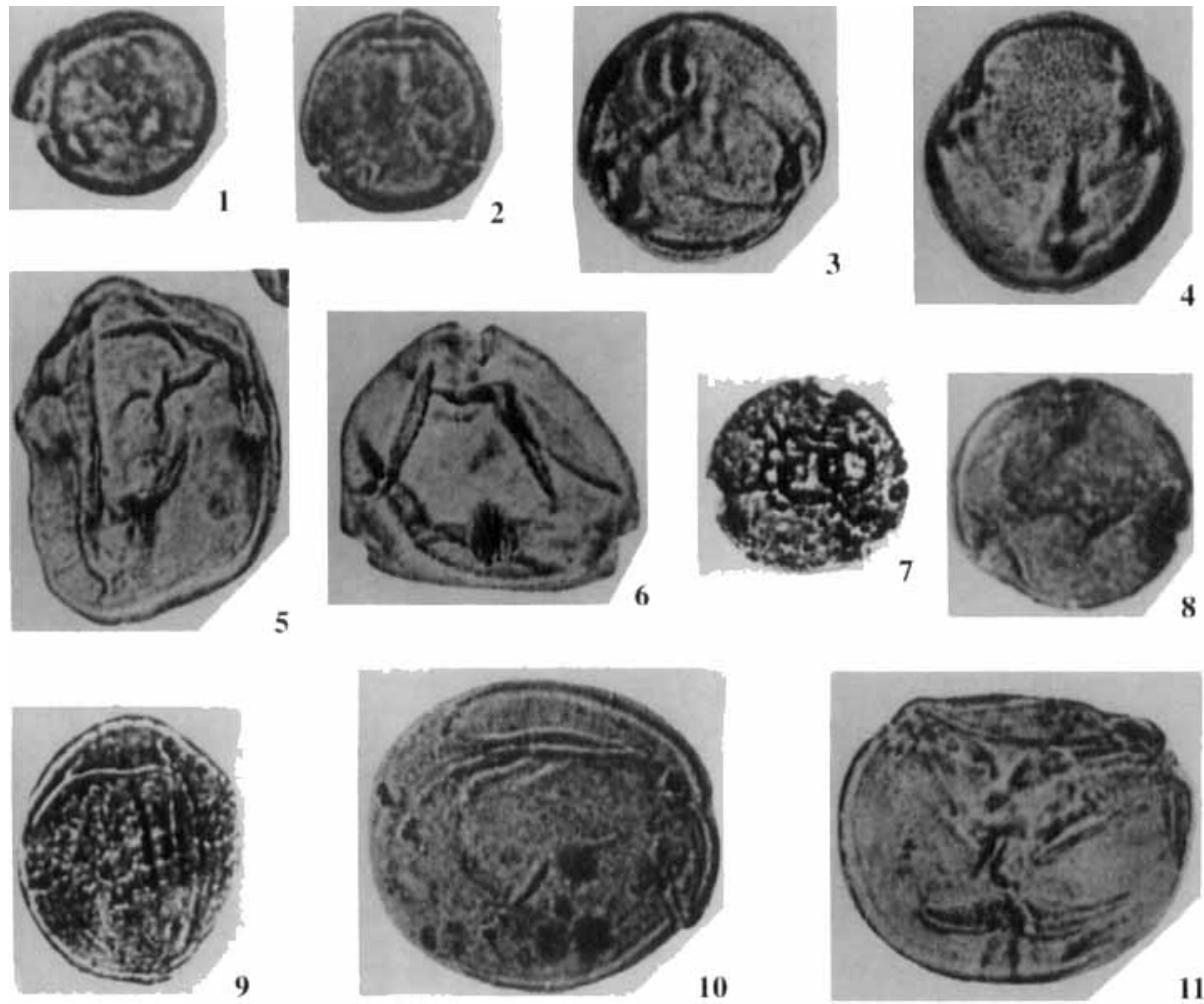

Plate. 1, 2. Faguspollenites par vifossilis (Traverse) Yu, Gao et Mao - North of Jiangsu Province, southeast China; $\mathrm{Pa}-$ laeocene, Taizhou Formation. 3, 4. Faguspollenites mediocris Zheng - Bohai Sea; Miocene, Guantao Formation. 5, 6. $\mathrm{Fa}$ guspollenites changheensis $\mathrm{Li}$ - Cixi County, northeastern Zhejiang Province, southeast China; Palaeocene-Eocene, Changhe Formation. 7, 8. Faguspollenites verus Raatz. 7. Coastal region of Bohai Sea; Late Eocene, Shahejie Formation; 8. Songci County, Hubei Province, central China; Eocene, Pailoukou Formation. 9. Faguspollenites pseudocruciatus Potonie - Jianghan Plain, Hubei Province, central China; Oligocene, Qianjiang Formation. 10, 11. Faguspollenites koraiensis Takahashi - Shelf basin of East China Sea. 10. Pliocene, Santan Formation; 11. Miocene, Yuquan Formation humidity must have been fairly low and temperature quite high for Fagus (Guo 1985, 1990; Zhang 1990; Li \& Zheng 1995). Moreover, the big and oily seeds of Fagus do not likely germinate if they are exposed to dry conditions for a longer period of time (Hong \& An 1993). The only explanation is that the ecological requirements of the ancient Fagus may have changed. If that is the case, Fagus in the past could have been adapted to wider water and heat requirements than the extant beeches, and of course this must be a good example that palaeoclimatic reconstruction by means of comparison with living equivalents should be considered with caution. Another possibility is that the dry and warmer climates are not as severe as has been assumed and they are probably not beyond the ecological tolerance of Fagus. Unlike fossil leaves, palynological data are somewhat limited to allow palaeoclimatic reconstruction quantitatively. Therefore, more macrofossil materials especially leaves are required to evaluate further the palaeoecological parameters of Fagus (see Wolfe 1993).

Oligocene floras are relatively rare in China. However, both the beech leaves and the pollen from the Oligocene show significant distribution patterns (Fig. 5). It is very obvious that beeches seemed to return to northeast China in the Late Oligocene. In northeast China, only megafossils of Fagus are reported from a single flora (Guo
1992). The leaves are the earliest undoubted macrofossil records of Fagus from China. These fossils include at least two leaf types in which one type is near to Fagus lucida Rehder et Wilson and the other to $F$. engleriana Seemen and F. multinervis Nakai (Liu et al. 1996). Fagus multinervis Nakai is now endemic to Ulleung-do Island of South Korea. The Oligocene beech leaves from northeast China appear to be similar to the East Asian species only. In addition, the Oligocene flora shares numerous genera (e.g. Pinus, Castanea, Quercus, Acer, some members of Rosaceae and Leguminosae) with the living beech forests (see Guo 1992). As far as pollen records of Fagus from other parts of China are concerned, their occurrences are again very low in every assemblage ( $\mathrm{Li}$ et al. 1978; Zhao et al. 1982; Wang et al. 1987; Anonymous 1989).

The climatic cooling in the Oligocene probably explains why beeches reappeared in northeast China. This is simply because beeches request moderate temperature and much humidity. In northeast China, the climate in the Eocene was warmer and somewhat drier than that in the Palaeocene (Guo 1985). Therefore, the beeches might temporarily disappear there in the Eocene.

From a floristical point of view, the Early Tertiary fossil floras containing beeches from south-central China appear to share numerous genera with the living beech forests (e.g. Quer- 


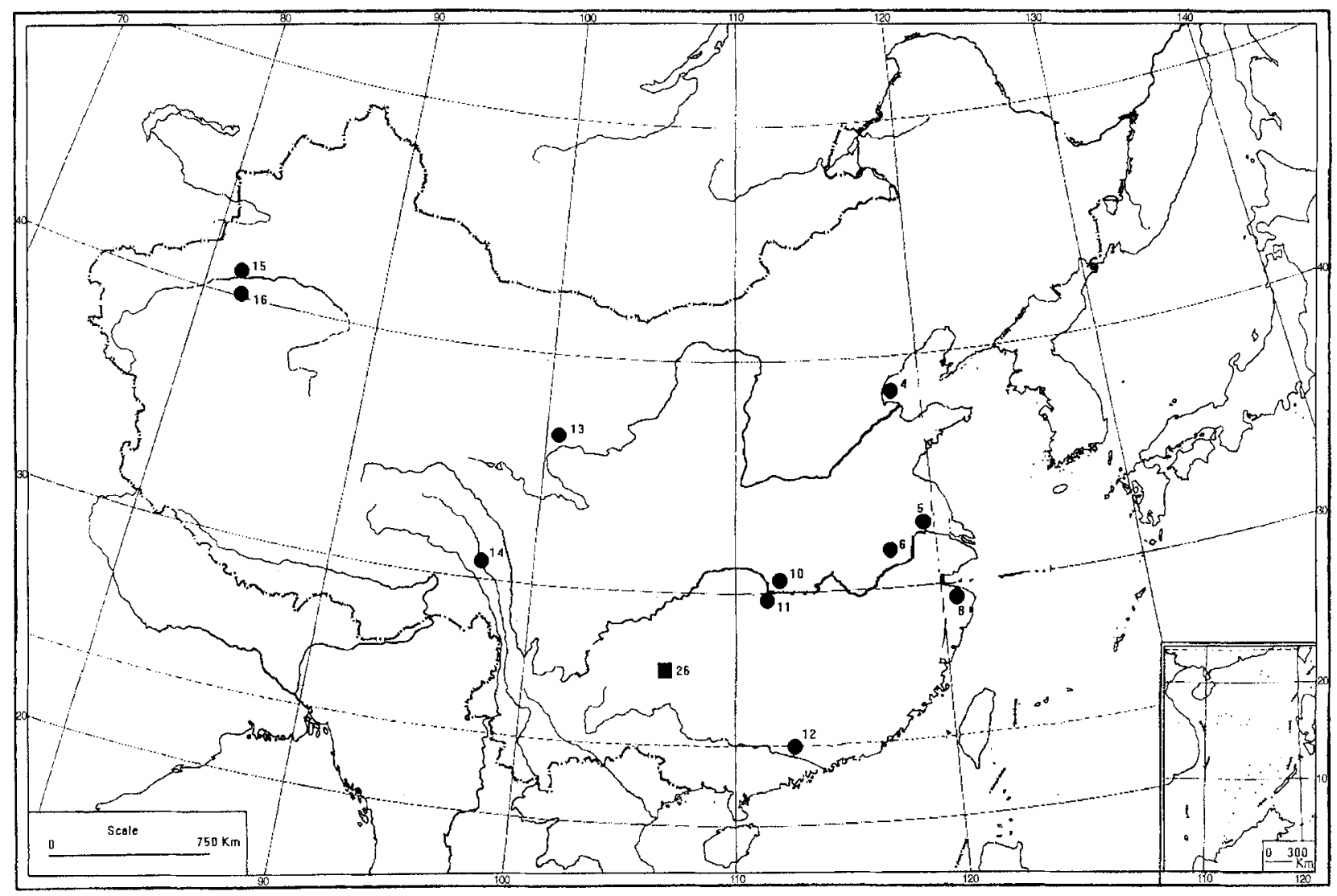

Fig. 4. Occurrences of Fagus in the Eocene (the Arabic numerals correspond to the number of localities in Tables 3, 4). Round dot $=$ fossil pollen, and square $=$ megafossil

cus, Nyssa, Symplocos, Rhus, Betula, Carpinus, and Fraxinus). But the difference is still very big. A number of genera which are now not found in the living beech forests any more are often dominant in those fossil floras. These genera include, e.g. Ulmipollenites (Ulmaceae) (Anonymous 1978; Wang \& Zhao 1980; Song et al. 1981, 1986), Lonicerapollenites (Caprifoliaceae) (Song et al. 1986), Engelhardtioidites, Caryapollenites (Juglandaceae) (Anonymous 1978; Song et al. 1981; Song \& Li 1982), Alnipollenites and Ostryoipollenites (Betulaceae) (Song et al. 1981), Myricipites (Myricaceae) (Wang \& Zhao 1980), Myrtacidites (Myrtaceae) (Song et al. 1986), Araliaceoipollenites (Araliaceae) (Wang \& Zhao 1980), and Liquidambarpollenites (Hamamelidaceae) (Anonymous 1978).

In addition, the fossil forests containing Fagus seem to have been much more diverse than the living ones. As stated above, the living beech forests in China are generally attributed to mixed evergreen and deciduous broadleaved forests. Conifers and xerophytes do not occur in the living forests. However, coniferous or/and xerophilous species such as Cedripites, Podocarpidites, Pinuspollenites, Pterisisporites, and Ephedripites appear to be quite common in the beech-containing fossil assemblages, particularly in the northwestern part of China (see Zhao et al. 1982; Wang et al. 1990). Therefore, the fossil evidence from the Palaeogene of China shows a great difference existing between the fossil beech forests and the living ones.

In conclusion, Palaeogene Fagus always appears in a low percentage in every flora. That may suggest that Fagus in China had never taken a key place in ancient floras during the Early Tertiary. Fagus might first appear in China in the Late Cretaceous. In the Palaeocene, Fagus was widely distributed in different climates. But it further expanded its distribution southward in the Eocene while it retreated from the northeast. They seemed to survive in a dry and warm climate during that period. Beeches could be back to northeast China during the Oligocene worldwide climate cooling. Therefore, Palaeogene beeches lived in different habitats and associated with dissimilar plants as compared with the living beeches.

3. Fagus in the Neogene: In the Late Tertiary, the distribution of Fagus was strongly re- 


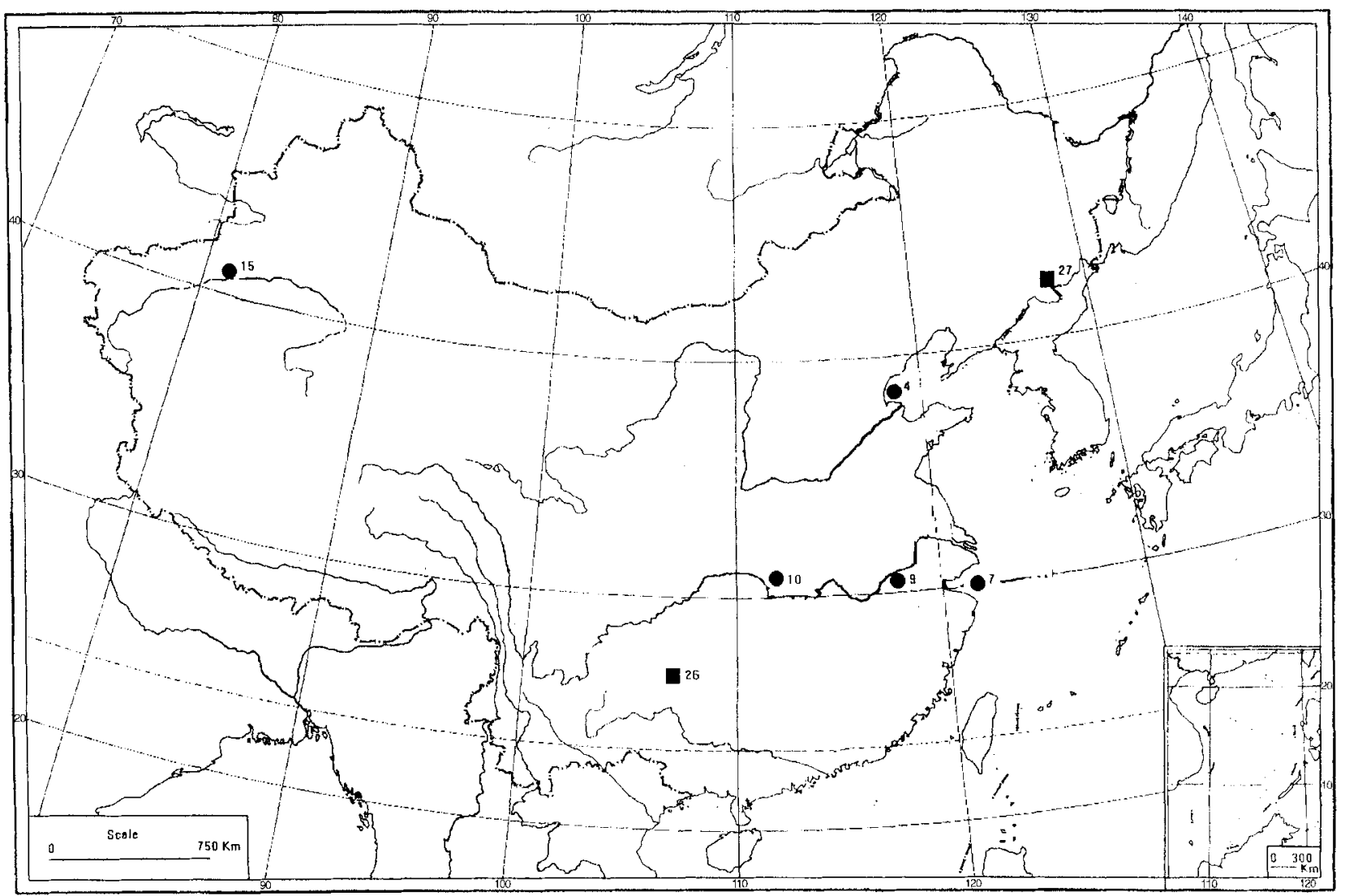

Fig. 5. Occurrences of Fagus in the Oligocene (the Arabic numerals correspond to the number of localities in Tables 3, 4). Round dot $=$ fossil pollen, and square $=$ megafossil

duced and confined to the eastern part of China (Figs 6, 7). The retreat of Fagus seems to be in accordance with the climatic changes in East Asia due to the Himalayan movements since the Oligocene (see Yin et al. 1988). The atmospheric currents changed completely by the uplift of the Himalayan Mountains. That enhanced the monsoon climate in east China and the continental climate in northwest and northern China (Hong \& An 1993). That might explain the absence of Fagus fossils in northwest China (see Wang 1994).

There are rare pollen records of Fagus from the northern part of east China, where all the Chinese Miocene Fagus leaves are found (see Depape 1932; Li \& Yang 1984; Liu et al. 1995). In that area, there seem to have been no more subtropical floras after the Oligocene (Guo 1985, 1990; Zhang 1995). The fossil leaves show the highest diversity morphotypic and specific in the Chinese Tertiary (Table 4; Liu et al. 1996; Leng 1997). A good example is the study of five leaf species from Huanan County, northeast China (Leng 1997). The five species are Fagus antipofii Heer, F. altaensis Kornilova et Rajushk., F. florinii Huzioka et Takahashi, F silesiaca Walther et
Zaskawniak and Fagus sp. The former three species are common elements in the East Asian Tertiary floras. The occurrence of Fagus silesiaca in China is very interesting as the species is common in the European Mio-Pliocene (Walther \& Zaskawniak 1991). This indicates that during the Miocene floristic exchanges between China and other parts of Eurasia occurred. However, the species composition of these Chinese Miocene floras is still very different from that of modern beech forests, e.g. the flora from Dunhua County, northeast China ( $\mathrm{Li} \&$ Yang 1984). The Miocene flora is considered as a mixed northern hardwood and flourishing in a warm temperate climate (Liu \& Zheng 1995), which is completely different from the modern Chinese beech forests. Except for a single conifer genus (Pinus), all the other seven out of fourteen genera (Pseudolarix, Cunninghamia, Glyptostrobus, Sequoia, Taxodium, Metasequoia and Cupressus) can not be found any more in the living beech forests in China. A recently found flora from Huanan County (Liu et al. 1995) also shows similar difference.

Palynological records reveal similar trends of beech forest development. The percentage of 


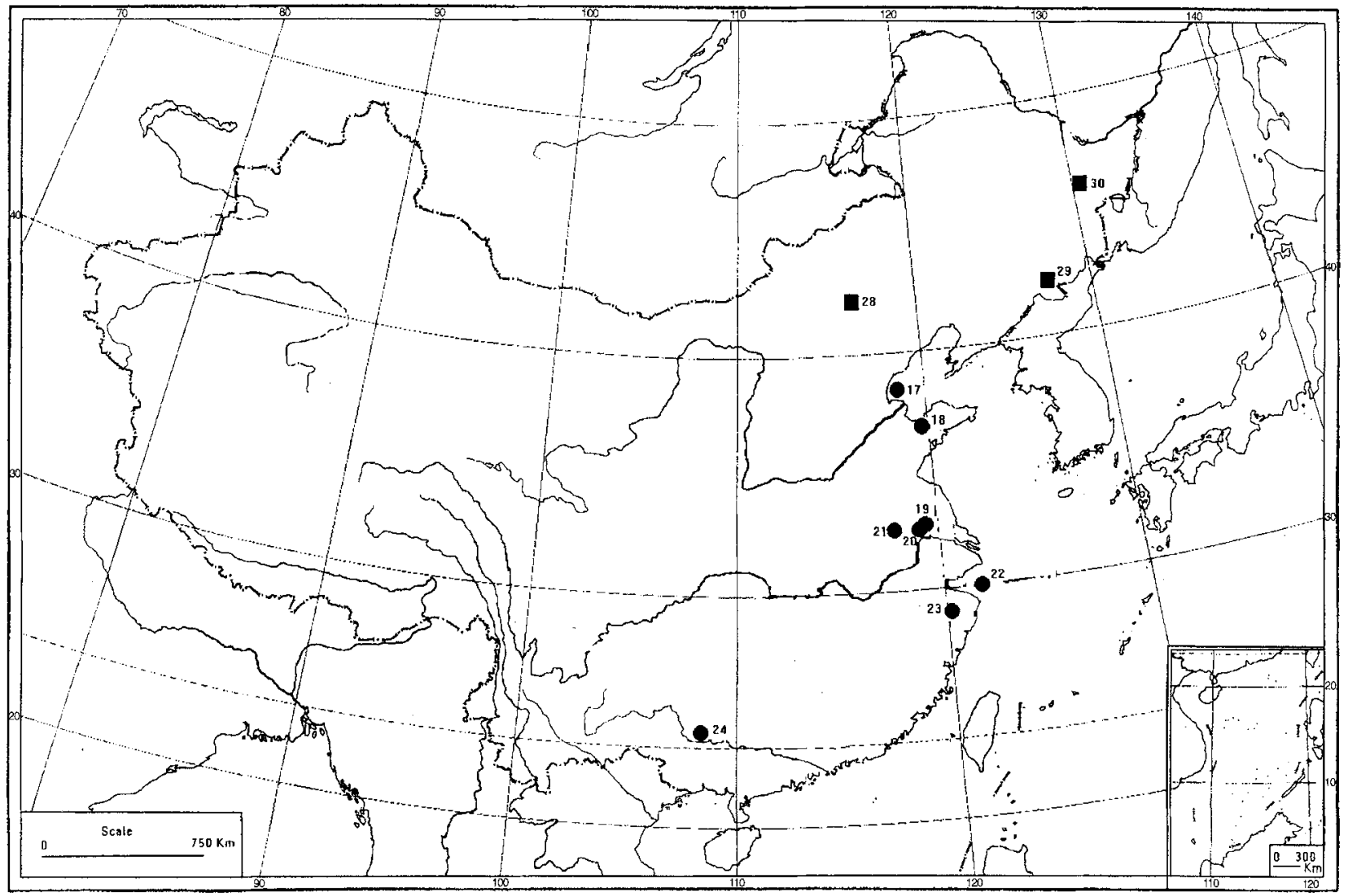

Fig. 6. Occurrences of Fagus in the Miocene (the Arabic numerals correspond to the number of localities in Tables 3, 4). Round dot $=$ pollen record, and square $=$ megafossil. Fossil pollen grains of Fagus have also been discovered in Huanan County (round dot $=$ No. 30), but they have not been reported in detail yet (see Liu et al. 1995)

Fagus pollen in most of assemblages has fairly increased during the Late Tertiary (Table 3 ). The Shanwang flora has the highest percentage of Fagus varying between 2.8 to $8.1 \%$ (Liu \& Leopold 1992). These latter authors pointed out that the flora should favor the flourish of Fagus as both the temperature (mean annual temperature $=13.5-16.6{ }^{\circ} \mathrm{C}$ ) and water (annual precipitation = ca. $1,000 \mathrm{~mm}$ ) conditions could be optimum for Fagus (cf. Cao et al. 1995). However, the dominant elements in that flora are Pinus $(7.2-11.7 \%)$, Quercus $(10-19 \%)$, Ulmus (7.6-16.0\%), Juglans/Pterocarya (5.4-11.6\%) and Carya $(5.6-8.4 \%)$. Furthermore, no fossil leaves of Fagus have been found in the same strata for at least half a century (Liu et al. 1996).

Unlike in the Palaeogene, there were fewer types of forests containing beeches in the Miocene although more diverse forests had got to be developed as the then climatic differentiation resulted in a large vegetational differentiation in China during the Late Tertiary (see Wang 1994). During the Miocene, for instance, a subtropical climate controlled most of east China, where vegetations consisted of mixed coniferous and deciduous broadleaved forests in the north (Anonymous 1978a; Guan et al. 1989; Yamonoi et al. 1993), mixed evergreen and deciduous broadleaved forests in the central area (Song et al. 1981, 1985; Zheng \& Zhang 1986; Liu \& Leopold 1992) and evergreen broadleaved forests in the south (Wang 1989). These forests began to resemble the modern beech forests though the species composition is still different (see Song et al. 1981; Wang et al. 1985; Zheng \& Zhang 1986; Wang 1989; Liu \& Leopold 1992).

Pliocene floras containing Fagus are rare (Fig. 7). Fagus is again absent in northeast and even in north China because of severe cooling and a dry climate (Liu 1988), but it occurs along the east coast, in the southeast and in montane regions of southwest China (Anonymous 1978, 1989; Li \& Guo 1982; Song 1988). Moreover, their percentage in fossil assemblages decreases again. The scarce information on Pliocene floras in China may be due to the fact that only few floras have been studied (Liu 1988). Therefore, it is possible that Pliocene Fagus was more widely distributed in southern China than is revealed by the data presently available. 


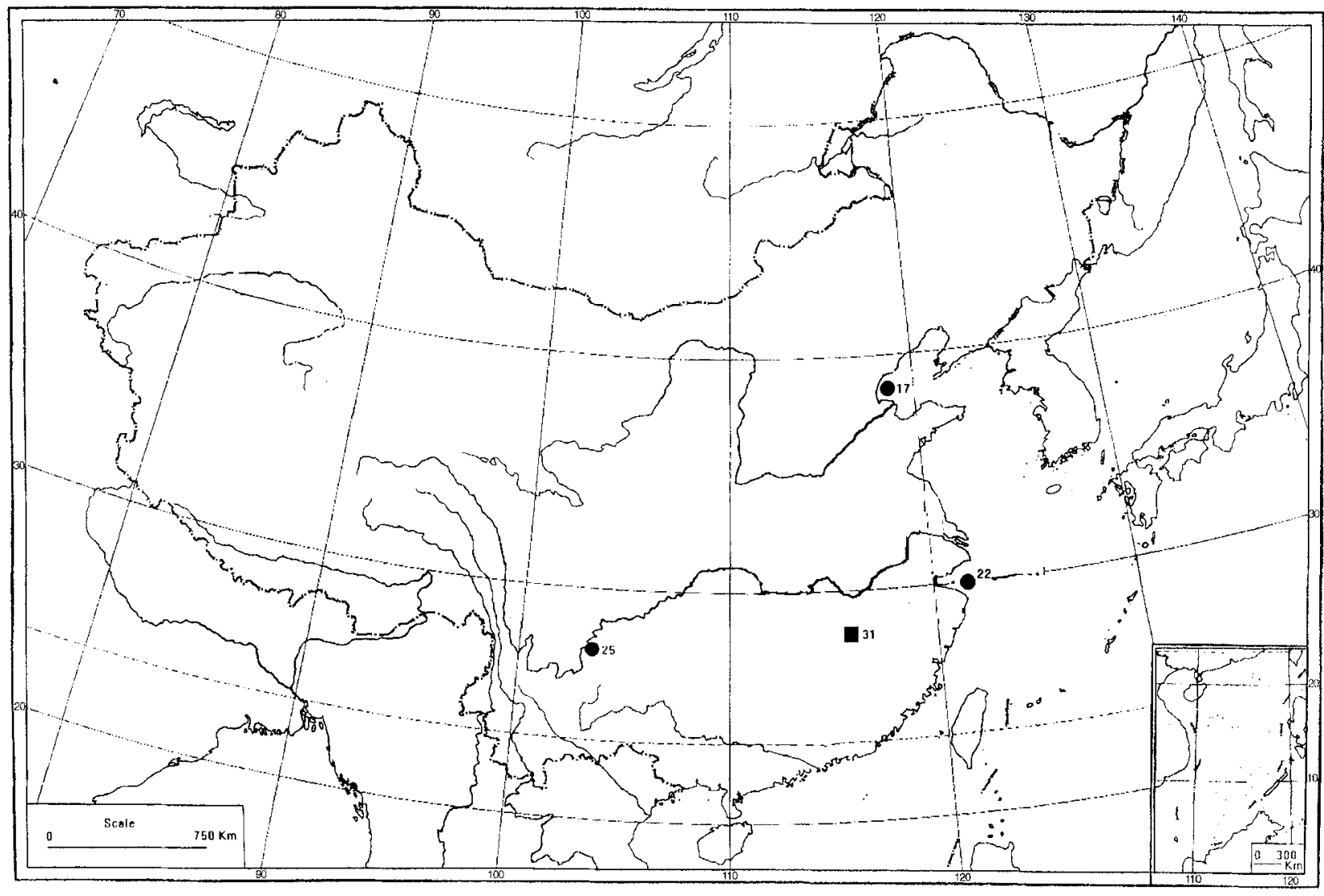

Fig. 7. Occurrences of Fagus in the Pliocene (the Arabic numerals correspond to the number of localities in Tables 3, 4). Round dot $=$ pollen record, and square $=$ megafossil.

In summary, the distribution of beeches in China was more restricted in the Neogene than during the Palaeogene. In the Miocene Fagus is most abundant in pollen assemblages and the diversity of leaf types. In comparison to the European Neogene, the proportion of beeches is still very low in China. Srodon (1985) reported that the maximum values of beech pollen in the Polish Neogene can exceed $20 \%$ and even $40 \%$. The abundance and diversity of the Chinese beeches obviously declined in the Pliocene. However, more information is still required. In the Neogene, especially in the Miocene, beeches still lived in different forest types from the modern Chinese beech forests. However, the differences might be smaller than in the Palaeogene. Therefore, the development of a modern distribution pattern and final fixing of their ecological requirements for modern Fagus should have happended even after the end of the Tertiary.

\section{Conclusions}

In pre-Quaternary deposits of China, pollen grains of Fagus often occur in rather low percen- tages. They might originate in the Cretaceous when sparse records exist. The Palaeogene fossils of the genus, however, scattered throughout China. Some survived in a humid and warm habitat in the northeast, while the remainder lived under dry and torrid conditions. The ancient forests containing Fagus probably share minor resemblance with the modern beech forests. In the Neogene, however, the distribution of Fagus was largely reduced. Particularly, beeches retreated from the northern and northwestern regions of China. This is probably because those areas had become too cold and arid for beeches to exist after the Oligocene. But Fagus started to differentiate in east China and finally reached its peak of diversity. Exchange of Fagus species was then possible among China, Europe, Far East and Japan. It must be stated that it is not possible at the moment to compare the Chinese fossil beeches with those in other parts of the world due to poor preservation of the Chinese species. Based on scrappy records of beech leaf fossils from China, the Chinese beeches apparently developed more or less independently during the Tertiary. More materials however are required. In addition, the Neogene forests with Fagus have 
Table 5

Comparison between fossil and modern beech forests in China.

\begin{tabular}{|c|c|c|c|}
\hline Item & Palaeogene beeches & Neogene beeches & Modern beeches \\
\hline $\begin{array}{l}\text { 1. Distribution } \\
\text { (1) region } \\
\text { (2) altitude }\end{array}$ & $\begin{array}{l}\text { most widely } \\
\text { lowland }\end{array}$ & $\begin{array}{l}\text { east \& southwest China } \\
\text { relatively high }\end{array}$ & $\begin{array}{l}\text { south China } \\
\text { montane }\end{array}$ \\
\hline 2. Occurrence & sparse & slightly increased & dominate element/pure stands \\
\hline $\begin{array}{l}\text { 3. Ecology } \\
\text { (1) temperature } \\
\text { (2) humidity }\end{array}$ & $\begin{array}{l}\text { highest } \\
\text { lowest }\end{array}$ & $\begin{array}{l}\text { higher } \\
\text { moderate }\end{array}$ & $\begin{array}{l}\text { moderate } \\
\text { high }\end{array}$ \\
\hline $\begin{array}{l}\text { 4. Forest } \\
\text { (1) type } \\
\text { (2) associate species }\end{array}$ & $\begin{array}{l}\text { most diverse } \\
\text { Pinus, Ephedra } \\
\text { Podocarpus, } \\
\text { Taxodiaceae; } \\
\text { Ulmus, Ostrya, } \\
\text { Quercus, Rhus }\end{array}$ & $\begin{array}{l}\text { numerous } \\
\text { Pinus, Tsuga } \\
\text { Picea, Keteleeria; } \\
\text { Ulmus, Carya, } \\
\text { Juglans Alnus, } \\
\text { Betula, Quercus . . }\end{array}$ & $\begin{array}{l}\text { a few } \\
\text { Pinus, Abies, Cathaya; } \\
\text { Juglans, Fagaceae, } \\
\text { Lauraceae, Theaceae, } \\
\text { Rosaceae... }\end{array}$ \\
\hline
\end{tabular}

more genera common as compared with the modern beech forests of China. One of the most evident floristic changes is the decline of Ulmipollenites from a higher percentage ( $>15 \%)$ in the Palaeogene to a relatively low content $(5-10 \%)$ in the Miocene. As we have mentioned above, taxa of the Ulmaceae are no longer found in the modern beech forests. Pliocene cooling climate might again reduce the distribution areas of Fagus. In a word, as its often low contents in occurrence, Fagus had never been an important element in the Chinese Tertiary vegetation. It is believed that the final development of the Chinese modern beech forests might be possible after the Tertiary.

The differences in distribution, floristic composition, and ecological characters between the pre-Quaternary Fagus and the modern ones in China are summarized in Table 5.

\section{Acknowledgments}

We thank Prof. Dr. Dieter Mai and Dr. Stephan Schultka (Berlin, Germany) for their help in many ways during the whole work, Dr. Dave Lazarus (Berlin, Germany) for his professional aid of computer mapping, and Mrs. Qin Leng, Prof. Shuang-Xing Guo (Nanjing, China) and two anonymous reviewers for giving invaluable data and critical discussion. This study was financed by the Alexander von Humboldt Research Fellowship (YSL) which is gratefully acknowledged.

\section{References}

Anonymous 1976. Cretaceous Sporo-Pollen Assemblages from the Songliao Basin. 83 pp., Science Press, Beijing.

Anonymous 1978. Early Tertiary Spores and Pollen Grains from the Coastal Region of Bohai, 177 pp., Science Press, Beijing.
Anonymous 1989. Cenozoic Paleobiota of the Continental Shelf of the East China Sea (Donghai). Micropaleobotanical Volume. 324 pp., Geological Publishing House, Beijing.

Anonymous 1992. Fagaceae. In Wang Jing-Xiang (ed.). Flora of Zhejiang, Volume 2. Casuarinaceae - Lauraceae: 41-66, Zhejiang Science and Technology Publishing House, Hangzhou.

Chang Yong-Tian \& Huang Cheng-Chiu 1988. Notes on Fagaceae (II). - Acta Phytotaxonomic Sinica 26(2): $111-119$.

Cao Kun-Fang, Peters, R. \& Oldeman, R.A.A. 1995. Climatic range and distribution of Chinese Fagus species. - Journal of Vegetation Science 6: 317-324.

Depape, G. 1932. La flore Tertiaire du Wei-Tch'ang (Province de Jehol, Chine). - Publication of Museum in Hoangho (6): 1-26.

Guan Xue-Ting, Fan Hui-Ping, Song Zhi-Chen \& Zheng YaHui 1989. Researches on Late Cenozoic Palynology of the Bohai Sea. 152 pp., Nanjing University Press, Nanjing.

Guo Shuang-Xing 1985. Preliminary interpretation of Tertiary climate by using megafossil floras in China. - Palaeontologia Cathayana (2): 169-176.

- 1990. A brief review on megafloral successions and climatic changes of the Cretaceous and Early Tertiary in China. In Knobloch, E. \& Kvacek, Z. (eds.), Proceedings of the Symposium "Paleofloristic and Paleoclimatic Changes in the Cretaceous and Tertiary", IGCP Project No. 216: 23-38, Geological Survey Publisher, Prague.

- 1992. Cenozoic plants. In Bureau of Geological and Minerological Resources, Jilin Province (ed.), Paleontological Atlas of Jilin, China: 563-580, Jilin Science and Technology Publishing House, Changchun.

Hong Bi-Qong \& An Shu-Qing 1993. Preliminary studies on the geographic distribution of Fagus in China. - Acta Botanica Sinica 35(3): 229-233.

Kvacek, Z. \& Walther, H. 1991. Revision der mitteleuropäischen tertiären Fagaceen nach blattepidermalen Charakteristiken IV. Teil Fagus Linne. - Feddes Repertorium 102: $471-534$.

Lei Yi-Zhen, Guan Shao-Zheng, Zhang Qing-Ru \& Sun SuYing 1987. Biostratigraphy of the Yangtze Gorge Area (5), Cretaceous and Tertiary. 404 pp., Geological Publishing House, Beijing.

Leng Qin 1997. Study on Fagaceae in Late Miocene Sifangtai flora from Huanan County, Heilongjiang, N.E. China. M.Sc. Thesis. 151 pp., Nanjing Institute of Geology and Palaeontology, Academia Sinica.

Li Hao-Min \& Guo Shuang-Xing 1982. Angiospermae. In Nanjing Institute of Geology and Minerological Resources (ed.), Paleontological Atlas of East China, Part 3, 
Volume of Mesozoic and Cenozoic: 294-316, Geological Publishing House, Beijing.

Li Hao-Min \& Yan Gui-Ying 1984. Miocene Qiuligou flora in Dunhua County, Jilin Province. - Acta Palaeontologica Sinica 23 (2): 204-217.

Li Hao-Min \& Zheng Ya-Hui 1995. Palaeogene Floras. In Li, Xing-Xue (ed.), Fossil Floras of China through the Geological Ages: 455-505, Guangdong Science and Technology Press, Guangzhou.

Li Man-Ying 1980. Eocene spores and pollen assemblage from northeastem Zhejiang. Paper for the 5th International Palynological Conference. Nanjing Institute of Geology \& Palaeontology, Academia Sinica, 9 pp.

Li Man-Ying, Song Zhi-Chen \& Li Zai-Ping 1978. Some Cretaceous-Tertiary palynological assemblages from the Yangtze-Han River Plain. - Memoirs of Nanjing Institute of Geology \& Palaeontology, Academia Sinica 9: 1-60.

Li Man-Ying \& Qing Guo-Rong 1994. Paleocene sporopollen from the Buxin Group of the Longgui Basin, Guangdong. - Acta Micropalaeontologica Sinica 11 (1): 55-69.

Liao Jih-Ching 1994. The taxonomic revisions of the family Fagaceae in Taiwan. (2nd Edition). 242pp., Department of Forestry, College of Agriculture, National Taiwan University, Taipei.

Liu Geng-Wu 1986. A Late Tertiary palynological assemblage from the Yaoshan Formation of Shanwang, Linju County, Shandong. - Acta Palaeobotanica and Palynologica Sinica 1: $65-84$.

- 1988. Neogene palynological sequence of northern China. - Acta Palaeontologica Sinica 27 (1): 75-90.

Liu Geng-Wu \& Leopold, E.B. 1992. Paleoecology of a Miocene flora from the Shanwang Formation, Shandong Province, North East China. - Palynology 16: 187-212.

Liu Geng-Wu, Li Hao-Min \& Leng Qin 1995. A preliminary report on Miocene flora from Daotaiqiao Formation of Huanan County, Heilongjiang Province, NE China. Acta Palaeontologica Sinica 34 (6): 755-757.

Liu Mu-Ling 1983. The late Upper Cretaceous to Palaeocene spore pollen assemblages from the Furao Area, Heilongjiang Province. - Bulletin of the Shenyang Institute of Geology and Mineral Resources, Chinese Academy of Geological Sciences 7: 99-132.

Liu Yu-Sheng, Guo Shuang-Xing \& Ferguson, D.K. 1996. Catalogue of Cenozoic megafossil plants in China. - Palaeontographica Abteilung B 238: 141-179.

Liu Yu-Sheng, Momohara, A. \& Mei Sheng-Wu 1996. A revision on the Chinese megafossil of Fagus (Fagaceae). Japanese Journal of Botany 71 (2): 168-177.

Liu Yu-Sheng \& Momohara, A. Infrageneric relationships of Fagus L. (Fagaceae) based on a cladistic analysis. - submitted to Botanical Journal of Linnean Society.

Liu Yu-Sheng \& Zheng Ya-Hui 1995. Neogene Floras. In Li Xing-Xue (ed.), Fossil Floras of China through the Geological Ages: 506-551, Guangdong Science and Technology Press, Guangzhou.

Peters, R. 1997. Beech Forests. Geobotany 24. 169 pp., Kluwer Academic Publishers, Dordrecht.

Praglowski, J. 1982. Fagaceae L.: Fagoideae. - World Pollen and Spore Flora 11: 1-28.

Shen Chung-Fu 1992. A monograph of the genus Fagus Tourn. ex L. (Fagaceae). Unpublished D.Phil. Thesis, The City University of New York.

Song Zhi-Chen 1988. Late Cenozoic palyno-flora from Zhaotong, Yunnan. - Memoirs of Nanjing Institute of Geology \& Palaeontology, Academia Sinica 24: 1-108.

Song Zhi-Chen, Guan Xue-Ting, Zheng Ya-Hui, Li ZengRui, Wang Wei-Ming \& Hu Zhong-Heng 1985. A Research on Cenozoic Palynology of the Longing Structural Area in the Shelf Basin of the East China Sea (Donghai) Region. 209 pp., Anbui Science and Technology Publishing House, Hefei.

Song Zhi-Chen \& Li Man-Ying 1982. Eocene palynological assemblage from the Gonjo Formation of Eastern Xizang.
In Anonymous (ed.), Stratigraphy and Paleontology of West Sichuan and East Xizang Area, Book 2: 7-27, Sichuan People's Press, Chengdu.

Song Zhi-Chen, Li Man-Ying \& Zhong Lin 1986. Cretacous and Early Tertiary Sporo-Pollen Assemblages from the Sanshui Basin, Guangdong Province. - Palaeontologia Sinica, New Series A, 171 (10): 1-170.

Song Zhi-Chen, Zheng Ya-Hui, Liu Jing-Ling, Ye Ping-Yi, Wang Cong-Fong \& Zhou Shan-Fu 1981. Cretaceous-Tertiary Palynological Assemblages from Jiangsu. $268 \mathrm{pp}$., Geological Publishing House, Beijing.

Srodon, A. 1985. Fagus in the forest history of Poland. Acta Palaeobotanica $25(1,2)$ : 119-137.

Tanai, T. 1974. Evolutionary trends of the genus Fagus around the northern Pacific Basin. - Birbal Sahni Institute of Palaeobotany, Special Publication (1): 62-83.

Tsien Cho-Po, Ying Tsung-Shen, Ma Cheng-Gung, Li Ya-Lu, Chang Che-Sung \& Ming Tien-Lu 1975. The distribution of beech forests of Mt. Fanching Shan and its significance in plant geography. - Acta Phytotaxonomica Sinica 13 (1): $5-18$.

Walther, H. \& Zastawniak, E. 1991. Fagaceae from Sosnice and Malczyce (near Wroclaw, Poland). A revision of orginal materials by Goeppert 1852 and 1855 and a study of new collections. - Acta Palaeobotanica $31(1,2)$ : $153-199$.

Wang Da-Ning \& Zhao Ying-Niang 1980. Late CretaceousEarly Paleogene sporopollen assemblages of Jianghan Basin and their stratigraphical significance. - Professional Papers of Stratigraphy and Palaeontology 9: 121-171.

Wang Da-Ning, Sun Xiu-Yu, Zhao Ying-Niang \& He ZouSheng 1990. Palynoflora from Late Cretaceous to Tertiary in some regions of Qinghai and Xinjiang. In Anonymous (ed.). The Study on the Micropaleobotany from Cretaceous-Tertiary of the Oil Bearing Basins in some Regions of Qinghai and Xinjiang: 1-180, China Environmental Science Press, Beijing.

Wang, Kai-Fa, Jiang Hui, Zheng Zou, Zhang Yong-Chang \& Wang Wei-Ming 1985. Sporo-pollen and siliceous algae assemblages from the intercalated bed of basaltic sediments in Tiantai, Xinchang, Shengxian of Zhejiang. Journal of Stratigraphy 9: 28-34.

Wang Kai-Fa, Zhang Yu-Lan, Wang Rong, Wang Jia-Wen, Wang Yong-Yuan, Wang Cong-Fong \& Qian Shao-Hua 1987. Cretaceous-Tertiary Palynological Assemblages from Anhui. 109 pp., The Petroleum Industry Press, Beijing.

Wang Ping-Li \& Chang King-Tang 1991. The pollen morphology in relation to the taxonomy and phylogeny of Fagaceae. - Acta Phytotaxonomica Sinica 29(1): $60-66$.

Wang Wei-Ming 1989. Spores and pollen grains from Miocene lignite deposit of Yalong Village, Yao Autonomous County, Guangxi, China. - Acta Palaeontologica Sinica 28: $786-802$.

- 1990. Some major external effects on successional proccesses of Cenozoic vegetation in China. In Jin Yu-Guan (ed.), Palaeoecology of China, Volume 1: 281-299, Nanjing University Press, Nanjing.

- 1992. Palynofloristic changes in the Neogene of south China. - Acta Micropalaeontologica Sinica 9 (1): 81-95.

- 1994. Paleofloristic and paleoclimatic implications of Neogene palynofloras in China. - Review of Palaeobotany and Palynology 82: 239-250.

Wolfe, J.A. 1993. A method of obtaining climatic parameters from leaf assemblages. - Bulletin of the United States Geological Survey (2040): 1-71.

$\mathrm{Xu}$ Yong-Chun, Huang Cheng-Chiu, Ren Xian-Wei \& Chang Yong-Tian 1985. Fagaceae. In Cheng Wan-Chun (ed.), Sylva Sinica, Tomus 2: 2198-2357, China Forestry Publishing House, Beijing.

Yamanoi, T., Wang Wei-Ming \& Li Jing-Rong 1993. A middle Miocene pollen flora of Core $\mathrm{CB}-20$, southwest end 
of Bohai Sea. - Japanese Journal of Palynology 39: $103-111$

Yin Ji-Xiang, Sun Xiao-Xing \& Wen Chuan-Fen 1988. Xigaze Group - the flysch successions of Xigaze forearc basin in south Xizang. - Memoirs of the Institute of Geology, Academia Sinica 3: 96-118.

Yu Jing-Xian, Guo Zheng-Ying \& Mao Shao-Zhi 1983. Cretaceous palynological assemblages from the district south of the Songhua River. - Professional Papers of Stratigraphy and Paleontology 10: $1-118$.

Zetter, R. 1984: Morphologische Untersuchungen an FagusBlättern aus dem Neogen von Österreich. - Beiträge zur Paläontologie von Österreich 11: 207-288.Zhang Ji-Hui 1978. Angiospermae. In Working Group of Stratigraphy and Paleontology in Guizhou (ed.), Paleontological Atlas of Southwest China, Volume of Guizhou, no. 2. Carboniferous-Quaternary: 488-491, Geological Publishing House, Beijing.

- 1983. Discovery of Old Tertiary flora from Panxian of Guizhou and its significance. - Papers of Stratigraphy \& Paleontology of Guizhou 1: 133-141.

Zhang Yi-Yong 1993. Lat Cretaceous palynofloras of China. - Acta Micropalaeontologica Sinica 10 (2): 131-157.
- 1995. Outline of Palaeogene palynofloras of China. Acta Palaeontologica Sinica 34 (2): 212-227.

Zhang Yi-Yong \& Qian Zhe-Shu 1992. Eocene palynofloras form the Dainan and Sanduo Formations in north Jiangsu with special reference to Eocene climatic changes in southeast China. - Acta Micropalaeontologica Sinica 9(1): $1-24$

Zhao Ying-Niang, Sun Xiu-Yu \& Wang Da-Ning 1982. Tertiary sporopollen assemblages from Shache and Kuche Basin, Xinjiang. - Bulletin of the Institute of Geology, Chinese Academy of Geological Sciences 4: 95-125.

Zheng Ya-Hui 1982. Miocene spore and pollen from Xianju and Ninghai, Zhejiang Province. In Anonymous (ed.), Selected Papers for the First Symposium of Palynological Society of China: 71-74, Science Press, Beijing.

Zheng Ya-Hui \& Zhang Shu-Wei 1986. An early Miocene palynological assemblage from drill Hole T103 in Tianchang, Anhui Province. - Acta Micropalaeontologica Sinica 3: $151-160$.

Zhou Guang-Yu \& Li Xin-Dong 1994. Species composition and structure of Chinese beech forests. - Natural History Research 3 (1): 21-26. 